\title{
Three New Species of the Genus Autocharis Swinhoe, 1854 (Lepidoptera: Crambidae, Odontiinae) from the Southern Arabian Peninsula
}

\author{
Michael Seizmair \\ Department of Entomology, Section Lepidoptera, Bavarian State Collection of Zoology Munich, Munich, Germany \\ Email address: \\ michael.seizmair@gmx.net \\ To cite this article: \\ Michael Seizmair. Three New Species of the Genus Autocharis Swinhoe, 1854 (Lepidoptera: Crambidae, Odontiinae) from the Southern \\ Arabian Peninsula. American Journal of Entomology. Vol. 4, No. 1, 2020, pp. 17-25. doi: 10.11648/j.aje.20200401.13
}

Received: March 15, 2020; Accepted: April 1, 2020; Published: April 14, 2020

\begin{abstract}
New taxonomic results on the genus Autocharis Swinhoe, 1854 (Lepeidoptera: Crambidae, Odontiinae) are presented on the basis of a sample of 11 specimens collected by the author in south-western Oman between 2017 - 2019 . The attribution of the material to the genus Autocharis Swinhoe, 1854 and the exclusion of other genera close to Autocharis Swinhoe, 1854 was done on the basis of differential features in the forewing venation. Examination of the wing pattern and the genitalia resulted in the attribution of one part of the sample (10 specimens) to the Autocharis seyrigalis (Marion \& Viette, 1956) species complex and of the other part (1 specimen) to the Autocharis fessalis (Swinhoe, 1886) complex. Morphpmetric analysis of the sample and comparison with type material of the respective species groups revealed significant differences between the specimens of the sample and the representants of the two species groups. These differences result in the description of three new species: Autocharis trisignalis Seizmair, sp.nov. Autocharis renalis Seizmair, sp.nov. belonging to the Autocharis seyrigalis (Marion \& Viette, 1956) complex and Autocharis arrondalis Seizmair, sp.nov. belonging to the Autocharis fessalis (Swinhoe, 1886) complex. Furthermore, the presence of the Autocharis seyrigalis (Marion \& Viette, 1956) complex is reported as new to the entomofauna of the Arabian Peninsula. Up to now, records of the Autocharis seyrigalis (Marion \& Viette, 1956) complex have been restricted to South Africa and the Malagasy region.
\end{abstract}

Keywords: Lepidoptera, Crambidae, Odontiinae, Autocharis, Taxonomy, Morphology, Arabian Peninsula

\section{Introduction}

The genus Autocharis Swinhoe, 1854 comprises according to present knowledge a total of 25 species. The genus is distributed in the Afrotropical, Oriental and Indo-Australian zones. In the Afrotropical zone the distribution presently known is centered on South Africa and on the Malagasy region, with further occurrences reported from East, Central and West Africa. The distribution of the genus reaches its northern most limit in the northern part of the Arabian Peninsula [1-3].

The genus is close to the genera Trigonoorda Munroe, 1974 and Pseudonoorda Munroe, 1974 with which it forms a complex of genera sharing a set of features in habitus and genital morphology. The most important common external features are triangular shaped forewings and a characteristic wing pattern characterized by a transverse band in the distal area, which is clearly distinct from the ground scaling. The central feature shared in the structure of the male genitalia is a fan-like shape of the valves, with extensive setose fields on the borders and a characteristic structure of several sclerites in the interior, which varies inter-specifically. The juxta area is triangular-shaped and the basis of the saccus more or less convex. One of the key features distinguishing the genus Autocharis Swinhoe, 1854 from the other two genera is the radial venation of the forewings: R2 and R3+4 are separate in the genus Autocharis Swinhoe, 1854. In the other two genera, R2 is stalked on R3+4 (Figures 3, 8, 11).

The genus Autocharis Swinhoe, 1854 is known to contain several species complexes $[4,5]$. Material recently collected on the southern Arabian Peninsula by the author is attributed to two of those species groups.

The first species group is addressed in the following as the Autocharis seyrigalis (Marion \& Viette, 1956) species 
group, the representants of which share characteristic features in the forewing pattern, namely a strongly sinuate dark postmedial line, a greyish-white ground with sporadic, irregularly scattered scales in the medial area, and prominent dark scales on the costal border. The species complex consists according to present knowledge of three known species [5]. Its hitherto known distribution is restricted to South Africa and the Malagasy region. The occurrence of the species complex is reported as new to the entomofauna of the Arabian Peninsula on the basis of material presented in this paper.

The second species group dealt with in the present paper is addressed in the following as the Autocharis fessalis (Swinhoe, 1886) complex. Its distribution ranges from Samoa over Africa to the northern part of the Arabian Peninsula [3, 5]. The representants of this species group resemble each other in characteristic features of the forewing pattern, namely a dark narrow transverse band which is quasi straight, with only very weak curvatures and a constant whitish to yellowish ground in the basal and medial areas. On the Arabian Peninsula the species complex is represented by Autocharis fessalis (Swinhoe, 1886). Up to now, the records of this oriental fauna element on the Arabian Peninsula have been restricted to the UAE [3]. No other species of the genus Autocharis Swinhoe, 1854 have been reported from the Arabian Peninsula up to now.

The genus is conjectured to contain numerous species still unknown, particularly in the Afrotropical region [6, 7]. Recent studies on the distribution and morpho-taxonomy of the genus have been done in Marion and Viette, in Shaffer and Munroe, in Viette and Guillermet, in Guillermet and in Maes [4, 5, 8-10].

\section{Material and Methods}

\subsection{Sampling}

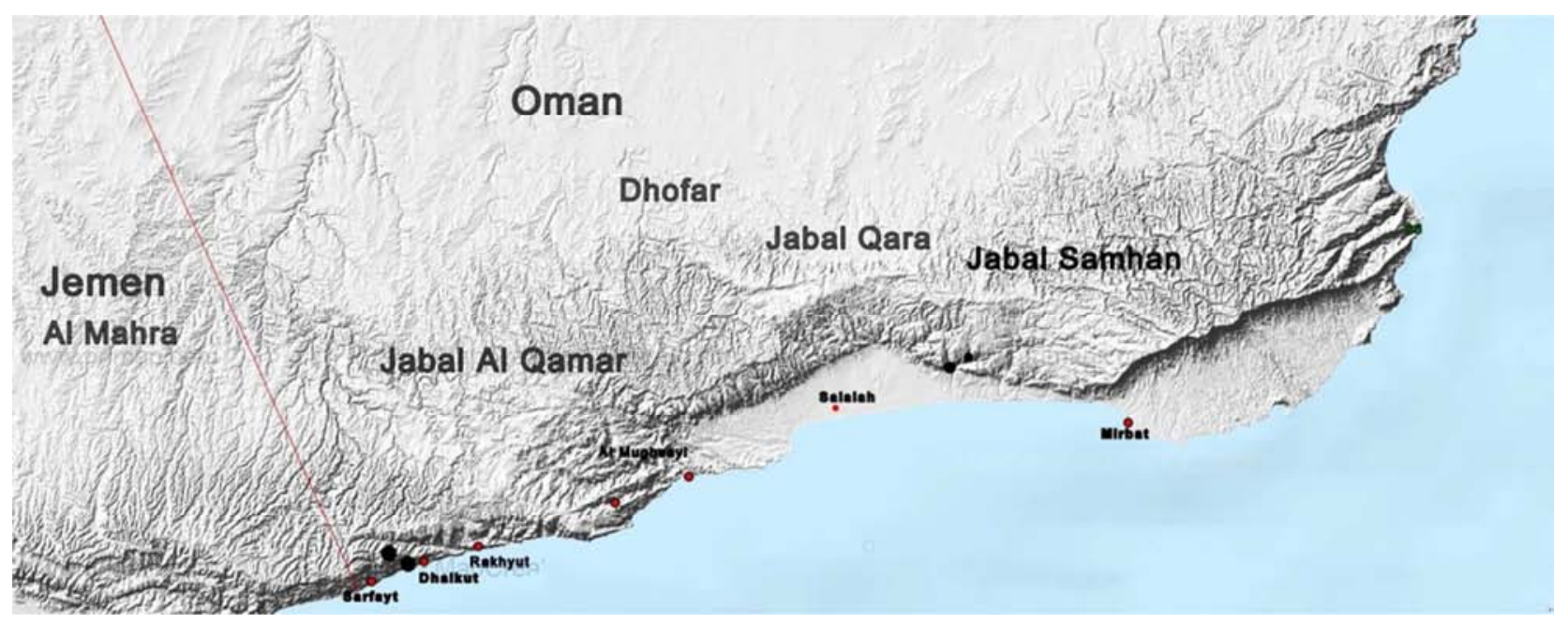

Figure 1. Sampling Locations in Dhofar / Oman (black points).

The material presented in this paper was sampled by the author in five research expedition to Dhofar, the south-western province of Oman between 2017 - 2019. The locations visited are situated in Jabal Al Qamar, a coastal mountain system ranging from the western surroundings of the province capital Salalah to the Yemen border (Figure 1). The specimens were captured at night by means of a light-trap equipped with a $20 \mathrm{~W}$ tube of infra-blue light.

\subsection{Macro-Preparation and Dissection}

Macro-Preparation was done on the specimens by spreading the wings and antennae. The prepared specimens were photographed with a SONY HX400V camera.

For examining the genitalia, dissection was done on the specimens on the basis of the protocol described in Robinson [11]. The slides were photographed with a SONY DSC100V camera under a 40x zoom.

The forewing venation was extracted by mounting the forewing in euparal. The resulting slides were photographed under a 20x zoom.

\subsection{Morphometric Analyses}

Morphometric analyses of wing patterns and genital-morphological structures were done on the images. Proportions between magnitudes were measured and calculated by means of the imaging software ZEISS AxioVision, Version 4.8.

\subsection{Terminology and Abbreviations}

The descriptions of the genitalia are based on the terminology in Maes, the descriptions of the wing patterns are based on the terminology in Slamka $[12,13]$. The terminology used in the descriptions of the venations follows Shaffer and Munroe [5].

Abbreviations:

ZSM Zoological State Collection Munich, Germany 


\section{Results}

Autocharis trisignalis Seizmair, sp. nov. (Figures $2-6$ ).

Material: Holotype: §ิ, Oman, Dhofar, $20 \mathrm{~km}$ E Sarfait, Jebel Al Qamar, 960 m, 25-XI-2019, leg. M. Seizmair, coll. ZSM, slide no. GPPYR3219. Paratypes: Oman, Dhofar, $20 \mathrm{~km}$ E Sarfait, Jebel Al Qamar, 960 m, 25-XI-2019, 6우이 leg. et coll. M. Seizmair, slide no. GPPYR3119, GPPYR3319 GPPYR3719, 07-XI-2018, 2ㅇ, slide no. GPPYR1019. GPPYR1119, leg. et coll. M. Seizmair.

Description: Wingspan of holotype $12,3 \mathrm{~mm}$, wingspan of paratypes 11, 5-12, $5 \mathrm{~mm}$. Head: ground scaling of frons and vertex black, interspersed with whitish-grey scales. Labial palpus 1, 2 times as long as the diameter of the eye, third segment half as broad as the first and second segments, scaling constantly black over all segments. Maxillary palpus whitish-grey, proportion length / diameter of eye 1 / 3 . Antennae filiform ciliate, flagellum black, cilia grey. Thorax: dorsal scaling brownish-black, with the metathorax interspersed with whitish-grey scales, ventral scaling whitish-grey. Abdomen: dorsal inter-segmental scaling black, interspersed with whitish-grey scales on the segments, ventral scaling whitish-grey. Fore- and hindlegs with whitish-grey scales inter-segmentally, with black scales on the segments.

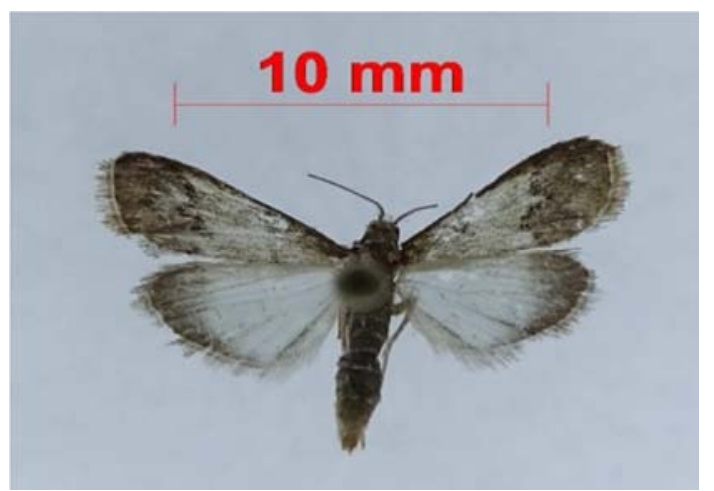

Figure 2. Autocharis trisignalis Seizmair, sp. nov, holotype, adult.

Forewing upperside: ground whitish-grey. Basal area interspersed with yellowish-brown scales. Antemedial und medial areas irregularly interspersed with dark-brown scales. Costal border dark-brown to black. Antemedial area with a very faint spot, immediately below the costal border, of irregular shape, with black border and white kernel. Antemedial line black, weakly drawn, strongly interrupted, beginning immediately beneath the subcostal spot. Postmedial and subterminal lines both dark-brown, strongly sinuate and quasi parallel. Postmedial area dark-brown to black. External area yellowish-brown, clearly distinguished from the darker postmedial area. Termen dark-brown to black. Fringe brownish-black. Apex rounded. Costal border straight. Termen convex. Dorsal border slightly concave. R2 and R3 separate, basal ends at the discoidal cell closely approximated. R1 and R2 widely separate, proportion of distances between the basal ends of R2-R3 and R1-R2 1 / 6 (Figure 3). Forewing underside like forewing upperside, yet with whitish-grey scales in the external area.

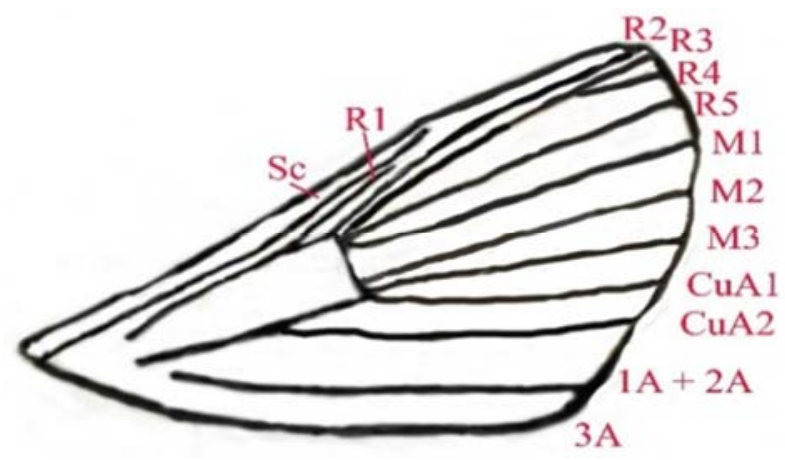

Figure 3. Autocharis trisignalis Seizmair, sp. nov, holotype, forewing venation.

Hindwing upperside: ground like forewing upperside, with a brownish-black transverse band covering the external and postmedial areas from the costal border to the M2, strongly narrowed from the $\mathrm{M} 2$ onwards and terminating at the $1 \mathrm{~A}+2 \mathrm{~A}$. Costal area with light-yellowish scales. $1 \mathrm{~A}+2 \mathrm{~A}$ covered with black scales all over its length. $\mathrm{CuA} 2$ covered with yellowish-brown scales over its distal third. Color of the termen and the fringe like in forewing. Costal and dorsal borders straight. Termen straight up to the M1, further on with a convex angle. Tornus rounded. $\mathrm{CuP}, 1 \mathrm{~A}+2 \mathrm{~A}$ and $3 \mathrm{~A}$ closely approximated.

Male genitalia (Figure 4): Valvae 1, 3 times as long as wide, apex broad at the basis, acute distally, occupied with a setose tuft. Interior of the apex with a fine sclerotised ridge with a $90^{\circ}$ sinus extending over its distal fifth. Distal end of the costal border with a fine projection near the apex, equal in length to $58 \%$ of the maximum width of the valva. Fibula long, slightly curved, equal in length to 3 / 4 of the width of the valva. The valva is divided in the middle by a tube-like sclerotised ridge developing from the base, ending at the apex and forming a Vshaped structure with the fibula, with long setae sporadically scattered all over its length. Sella long, fine, with a convex curvature extending over its first proximal third, acute distally, rounded at the proximal end, basis of irregular shape. Sacculus narrow, short, equal in length to one third of the width of the valva. Uncus bi-lobed, lobes rounded distally, with a deep antero-lateral concavity extending over the proximal half. Gnathos quasi rectangular, distal end slightly broader than basis, equal in length to the lobes of the uncus. Anellus divided into two ovoid lobes. Saccus convex, divided into two triangular lobes, which are acute proximally. Vinculum with a fine lateral projection. Aedeagus: straight with a slight sinus at the transition caecum - vesica, proportion length caecum / length vesica $1 / 4,8$, vesica strongly rounded, membranous. Caecum with a sclerite developing from the transition to the vesica and extending over $1 / 6$ of the length of the caecum. Posterior end of caecum with several fine, stroke-like sclerites. 


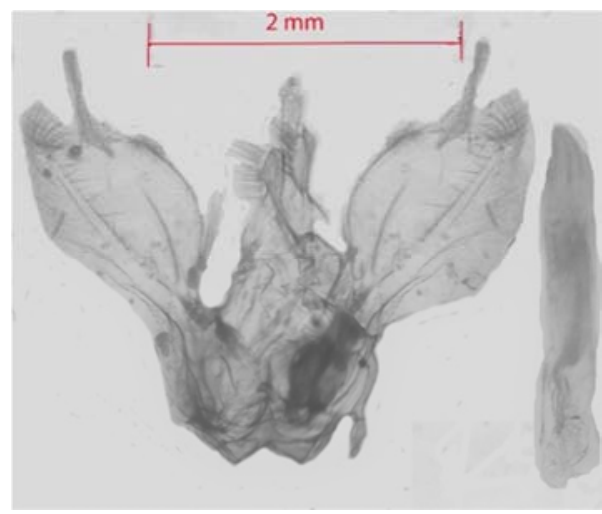

Figure 4. Autocharis trisignalis Seizmair sp. nov., holotype, male genitalia, slideno. GPPYR3219.

Female genitalia (Figure 5): Anal lobes quasi quadrangular, slightly rounded supero-laterally. Apophyses anteriores equal in length to the apophyses posteriores. Bursa copulatrix elongate, with the posterior half 1,3 times as wide as the anterior half, proportion maximal width / total length $1 / 2,5$, membranous except for three significant sclerites in the posterior half, namely two claviform signa laterally, one on each side, in between a third signum, which is significantly shorter than the two lateral ones and acute at its anterior end. Ductus bursae 2, 7 times as long as wide, with two fine lateral sclerites extending over its entire length. Ostium bursae semi-orbicular, with sclerotized plates laterally.

Tympanal organs (Figure 6): tympanum oviform, twice as long as broad, pons tympani very narrow, straight, acute distally, puteolus tympani strongly broadened, rounded at its anterior end, tergo-sternal sclerite triangular with a fine thorn-shaped projection.

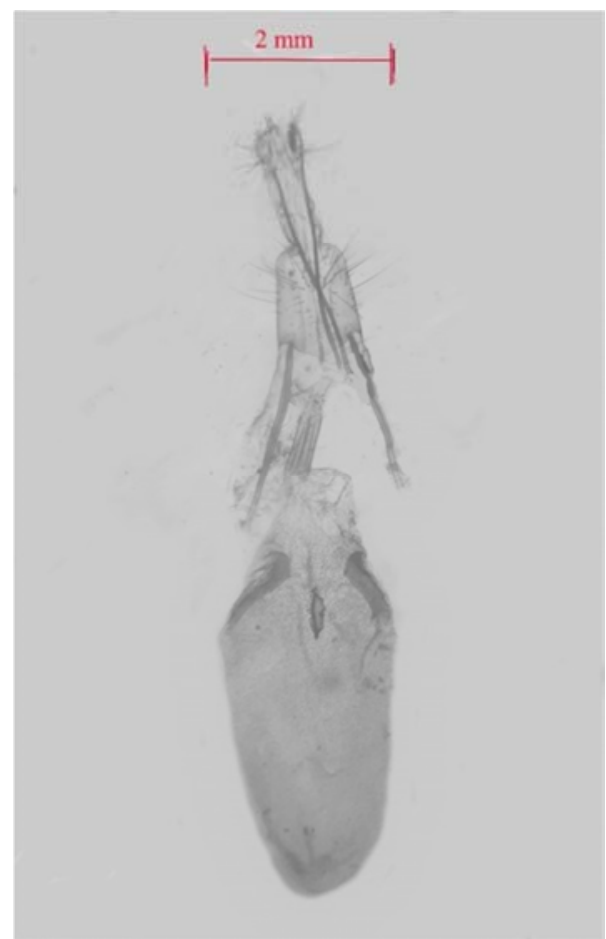

Figure 5. Autocharis trisignalis Seizmair, sp. n., paratype, female genitalia, slide no. GPPYR34195.

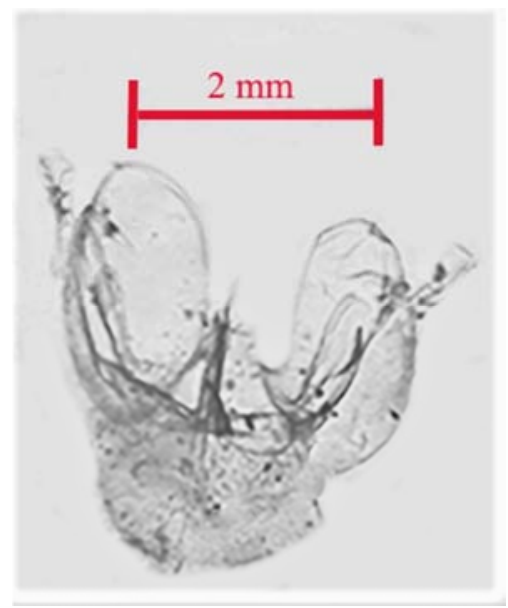

Figure 6. Autocharis trisignalis Seizmair, sp. nov., holotype,, tympanal organs.

Differential diagnosis: The species closest in habitus are Autocharis barbieri (LeGrand, 1966) and Autocharis seyrigalis (Marion \& Viette, 1956). The new species is distinguished form them externally as follows:

Forewing upperside: The scaling of the external area of Autocharis seyrigalis (Marion \& Viette, 1956) is greyish, the external and postmedial areas of Autocharis barbieri (LeGrand, 1966) are characterized by alternations of tufts of black and brownish fasciae. The scalings of both the postmedial area and the external area of the new species are constant, the postmedial area constantly brownish-black, the external area constantly yellowish-brown. Antemedial lines in Autocharis barbieri (LeGrand, 1966) and Autocharis seyrigalis (Marion \& Viette, 1956) well defined, antemedial line in the new species very faint and strongly broken.

Hindwing upperside: $\mathrm{CuA} 2$ and $1 \mathrm{~A}+2 \mathrm{~A}$ of the new species with black and brownish scales respectively, no scaling on the $\mathrm{CuA} 2$ or on the $1 \mathrm{~A}+2 \mathrm{~A}$ either in Autocharis barbieri (LeGrand, 1966) or Autocharis seyrigalis (Marion \& Viette, 1956).

Labial palpus: ground scaling black interspersed with white scales in Autocharis seyrigalis (Marion \& Viette, 1956), yellowish-ochre in the second and third segments and white in the first segment in Autocharis barbieri (LeGrand, 1966), constantly black in the new species.

The new species differs significantly in the male genitalia from Autocharis barbieri (LeGrand, 1966) and Autocharis seyrigalis (Marion \& Viette, 1956) in the following features. The male genitalia of Autocharis barbieri (LeGrand, 1966) are figured in Shaffer and Munroe, those of Autocharis seyrigalis (Marion \& Viette, 1956) in DePrins and DePrins and in Marion and Viette $[1,4,5]$.

Valvae: The new species is distinguished from the other two species by the elongate projection at the distal end of the costal border near the apex. Apex of the new species rounded distally, apex of the other two species acute distally. Sclerotised ridge combining with the fibula to a V-shape absent in Autocharis seyrigalis (Marion \& Viette, 1956) and replaced by a ridge developing from the medium of the costal border to the apex, present in Autocharis barbieri (LeGrand, 1966) reaching from 
the proximal fifth of the fibula to the beginning of the distal fifth of the dorsal border. In the new species it reaches from the base of the fibula to the apex, over the entire length of the valva. Valvae of Autocharis seyrigalis (Marion \& Viette, 1956) more elongate than those of the new species and of Autocharis barbieri (LeGrand, 1966). The valva of Autocharis seyrigalis (Marion \& Viette, 1956) is 2, 5 times as long as wide, the valvae of the new species and those of Autocharis barbieri (LeGrand, 1966) are 1, 3 times as long as wide.

Unci: Bases triangular-shaped in the new species, oviform in Autocharis barbieri (LeGrand, 1966), quadrangular-shaped in Autocharis seyrigalis (Marion \& Viette, 1956). Bases of Autocharis barbieri (LeGrand, 1966) with prominent thornshaped projections, which are absent in the new species and in Autocharis seyrigalis (Marion \& Viette, 1956). Lobes of the new species with prominent convex curvatures extending over the proximal half, which are absent in the other two species.

Gnathos: acute distally, broadened proximally in Autocharis seyrigalis (Marion \& Viette, 1956) and Autocharis barbieri (LeGrand, 1966), broadened and rounded distally, narrowed proximally in the new species.

Saccus: basis of Autocharis seyrigalis (Marion \& Viette, 1956) quasi flat, bases of the new species and of Autocharis barbieri (LeGrand, 1966) strongly convex forming two lobes, lobes of the new species acute proximally, those of Autocharis barbieri (LeGrand, 1966) rounded proximally.

Aedeagus: caecum straight in the new species, caecum with a $20^{\circ}$ - curvature in the other two species. Posterior end of the caecum acute in the new species, rounded in the other two species.

Furthermore, the new species differs from Autocharis barbieri (LeGrand, 1966) in the female genitalia in the following features. The female genitalia of Autocharis barbieri (LeGrand, 1966) are described and figured in Shaffer and Munroe [5].

Ductus bursae: half as long as the ductus bursae of Autocharis barbieri (LeGrand, 1966) and significantly wider.

Bursa copulatrix: several signa in the posterior half, which are absent in the bursa copulatrix of Autocharis barbieri (LeGrand, 1966). Significantly less wide than the bursa copulatrix of Autocharis barbieri (LeGrand, 1966).

Bionomics: Unknown. The types were collected in an escarpment zone in the coastal mountains near the Oman-Yemen border.

Distribution: Hitherto only known from the type locality in south-western Oman (Dhofar).

Etymology: The name refers to one of the differential features in the female genitalia, the three signa in the posterior half of the bursa copulatrix (latin: tri-=threefold, signum).

Autocharis renalis Seizmair, sp. nov. (Figures 7 - 9)

Material: Holotype: $\widehat{\jmath}$, Oman, Dhofar, $2 \mathrm{~km}$ W Sarfait, border Oman-Yemen, 780 m, 30-I-2017, leg. M. Seizmair, coll. ZSM, slide no. GPPYR1918.

Description: Wingspan of holotype: 9,60 mm. Head: ground scaling of vertex dark-grey interspersed with brownish scales. Frons whitish-grey. Antennae filiform ciliate, flagellum black, cilia light grey. Labial palpus constantly black over all segments, porrect, double as long as diameter of eye, acute distally, anterior border with a convex curvature, posterior border straight. Thorax: dorsal ground scaling of pro- and mesothorax black, interspersed with brownish scales, dorsal ground scaling of metathorax light brown interspersed with grey scales, ventral scaling of the entire thorax constantly ochre. Scaling of forelegs constantly whitish-grey. Ground scaling of hindlegs whitish-grey with black scales at their distal ends.

Forewing upperside: ground grey interspersed with yellowish-brown scales in the basal and medial areas. Basal and antemedial lines black, prominent and of irregular shape. Discal spot black, elongate, reniform, widely separated from the costal border. Postmedial line black, strongly sinuate. Postmedial and external areas dark brown. Termen and fringe yellowish-brown. Costal border at the radix slightly convex, then straight, with light brown scaling. Apex rounded. Termen convex at M2. Dorsal border straight. R2 and R3 separated, yet closely approximated at their basal ends on the discoidal cell. R1 and R2 widely separated. Proportion between distances of the basal ends R2-R3 / R1-R2 1/4. Forewing underside like forewing upperside (Figure 8).

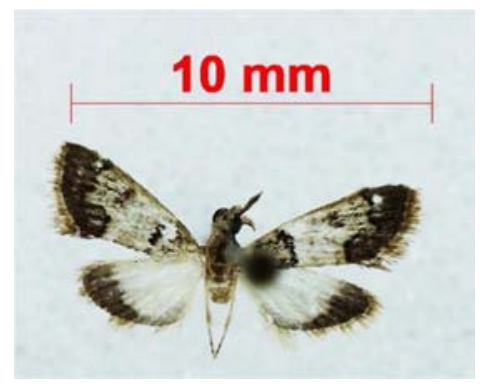

Figure 7. Autocharis renalis Seizmair, sp. nov., holotype, adult.

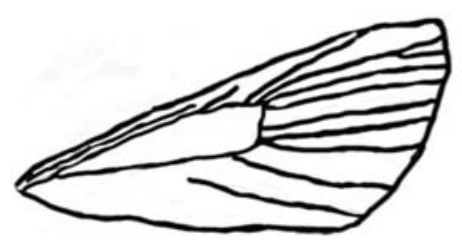

Figure 8. Autocharis renalis Seizmair, sp. nov., holotype, forewing venation.

Hindwing upperside: ground whitish-grey with a darkbrown transverse band occupying the external and postmedial areas between the costal border and $\mathrm{Cu} 2$, from $\mathrm{Cu} 2$ on significantly narrowed and restricted to the external area. Veins with yellowish scaling. Scaling of tornus and dorsal border dark-brown. Termen and fringe like in forewing upperside. Hindwing underside like hindwing upperside.

Male genitalia (Figure 9): Uncus bi-lobed, basis broad and rounded, lobes symmetrical, each of the lobes quasi triangular, acute distally. Gnathos equal in length to the lobes of the uncus, rounded distally, broadened at the basis. Valvae elongate, 1, 7 times as long as wide, apex acute distally, with a sclerotised ridge extending from the apex over the distal third of the valva. Fibula acute distally, elongate, equal in length to $40 \%$ of the valva. Saccus quasi flat. Aedeagus: Caecum rounded at the proximal end, narrowed at the transition to the vesica with an 
extended lateral sclerite, developing from the transition to the vesica. Vesica balloon-like, with a small, claviform sclerite, transition to the caecum sclerotised. Vesica double as long as wide, proportion length of vesica / length of caecum $1 / 1,2$, the length of the caecum making up $58 \%$ of the total length of the aedeagus.

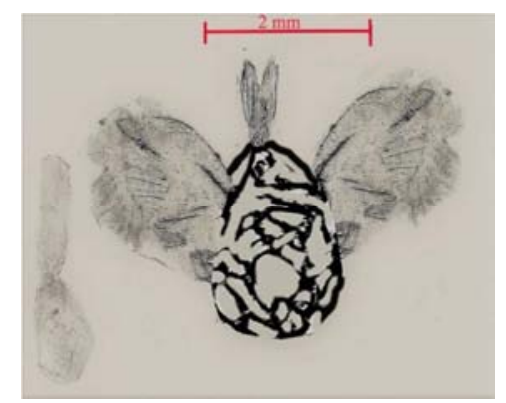

Figure 9. Autocharis renalis Seizmair, sp. nov., holotype, male genitalia, slide no. GPPYR1918.

Differential diagnosis: The closest species in habitus are Autocharis barbieri (LeGrand, 1966), Autocharis seyrigalis (Marion \& Viette, 1956) and Autocharis trisignalis Seizmair, sp. nov.. Autocharis renalis Seizmair, sp. nov. is distinguished from these species in habitus in the following features:

Forewing upperside: The postmedial and the external areas of Autocharis renalis Seizmair, sp. nov. are constantly brownish-black und do not differ in scaling. The postmedial and external areas of Autocharis trisignalis Seizmair sp. nov. are separated by the postmedial and subterminal lines and clearly distinguished in scaling. The postmedial and external areas of Autocharis barbieri (LeGrand, 1966) are interspersed with prominent tufts of black and grey fasciae. The external area of Autocharis seyrigalis (Marion \& Viette, 1956) is scaled greyish.

The postdiscal spot of the new species is prominent and reniform. The postdiscal spot in both Autocharis barbieri (LeGrand, 1966) and Autocharis seyrigalis (Marion \& Viette, 1956) is absent. The postdiscal spot in Autocharis trisignalis Seizmair sp. nov. is replaced by a faint subcostal antemedial spot.

Autocharis renalis Seizmair, sp. nov. differs significantly from the other three species in the male genital morphology in the following features: Unci: distal ends of lobes acute in the new species, rounded in all the other three species. Valvae: costal border of the new species quasi straight, costal borders of the other three species strongly convex or sinuate. The sclerotised ridge in the middle of the valva developing from the apex area combines to a V-shape with the fibula in Autocharis barbieri (LeGrand, 1966) and Autocharis trisignalis Seizmair, sp. nov.. In Autocharis seyrigalis (Marion \& Viette, 1956) it reaches from the apex to the medium of the costal border. In the new species the sclerotised ridge runs straight from the apex and is restricted to the distal fifth of the valva.

Aedeagus: Aedeagi of Autocharis barbieri (LeGrand, 1966) and Autocharis seyrigalis (Marion \& Viette, 1956) strongly curved on distal half, aedeagi of Autocharis renalis Seizmair, sp. nov. and Autocharis trisignalis Seizmair, sp. nov. quasi straight. Vesica of the new species and of Autocharis seyrigalis (Marion \& Viette, 1956) balloon-like and significantly broader than the caecum, in Autocharis barbieri (LeGrand, 1966) and Autocharis trisignalis Seizmair, sp. nov. the vesica is equal in width to the caecum.

Bionomics: Unknown. The type was collected in an escarpment at the border Oman-Yemen.

Distribution: Hitherto known from the type locality only. Neither endemism nor presence on the East African mainland can be excluded.

Etymology: The name refers to one of the external differential features in the habitus, the reniform discal spot on the forewing upperside (latin: renus).

Autocharis arrondalis Seizmair, sp. nov. (Figures 10 - 12)

Material: Holotype: $\hat{o}$, Oman, Dhofar, $20 \mathrm{~km}$ E Sarfait, Road 47, Jebel Al Qamar, 900 m, 26-XI-2019, leg. M. Seizmair, coll. ZSM, slide no. GPPYR3819.

Description: Wingspan of holotype 10,4 mm. Head: ground scaling of vertex dark-brown interspersed with grey scales. Frons black. Antennae filiform ciliate, flagellum black, cilia whitish-grey. Labial palpus elongate, broad, anterior border with a concave curvature, posterior border straight, distal ends acute, 2, 2 times as long as the diameter of the eye, proportion width / diameter of eye $1 / 2,4$, ventrally brownish-black, dorsally grey in the proximal half, black in the distal half, distal end with a small tuft of grey hairs. Maxillary palpus short, narrow, proportion length / diameter of eye 1 / 6 , scaling greyish-brown. Thorax: Scaling of pro- and mesothorax dorsally ochre, with broad greyish-white borders laterally. Scaling of metathorax whitish-grey dorsally and laterally. Ventral scaling of the entire thorax ochre. Scaling of fore- and hindlegs whitish- grey, tibial spurs present on hindlegs. Tegula yellowish-brown. Abdomen: intersegmental scaling whitish-grey, at the segments sporadically interspersed with black scales.

Forewing upperside: ground greyish-white, costal border with brownish-fulvous scaling in the basal, antemedial and medial areas. Broad brownish transverse band sporadically interspersed with yellowish scales making up distal $36 \%$ of the forewing scaling, with slight concave sinus at the R5, M3 and the $\mathrm{CuA} 2$. Sc and R1 quasi equidistant. R2 and R3 clearly separate, yet strongly approximate. Distance between basal ends on discoidal cell of R2-R3 four times greater than distance between basal ends of R1-R2 (Figure 11). Fringe brownish. Forewing underside like forewing upperside.

Hindwing upperside: ground greyish-white with a brownish transverse band in the external area reaching form the costal border to the $\mathrm{CuP}$, its width making up $27 \%$ of the length of the hindwing between the costal border and M3, strongly narrowed from M3 by 30\%. Hindwing underside like hindwing upperside.

Male genitalia (Figure 12): Valvae elongate, proportion maximum width / length $1 / 2,6$, costal border with a small tuft of setae in the middle, sinuate, with a convexity extending from the basis over $70 \%$ of the total length of the costal border, followed by a slight concavity up to the apex. Dorsal border 
with a tuft of long setae below the apex, slightly concave. Apex rounded, with a fine sclerotised ridge extending from the dorsal border immediately below into the interior of the valva equal in length to $43 \%$ of the entire valva. Fibula straight, elongate, equal in length to $46 \%$ of the entire valva and forming a V-shape with another sclerite which is 1, 4 times as long and ends at the beginning of the distal sixth of the dorsal border.

Uncus in the anterior two thirds triangular-shaped, in the posterior third oviform with several tufts of long setae. Gnathos considerably broadened in the distal fifth, mace-shaped.

Tegumen triangular-shaped, rounded distally, proportion maximum length / maximum width $1 / 1$. Juxta elongate, acute distally. Anellus consisting of two quasi oviform, membranous lobes with fine sclerites on the borders. Vinculum slightly convex. Basis of saccus strongly convex, divided into two lobes, which are rounded proximally.

Aedeagus: caecum 1, 6 as long as vesica, vesica oviform, with a fine, elongate sclerite, equal in length to $48 \%$ of the vesica, caecum strongly broadened and oviform in its posterior two thirds, posterior third 2, 3 times as wide as anterior third. Caecum with two cornuti in its oviform part.

Differential diagnosis: The closest species is Autocharis discalis Shaffer \& Munroe, 2007. The two species resemble each other in the broadened dark transverse band on the forewing upperside. The transverse band on the forewing of both species is significantly broader than that of the externally similar afrotropical species Autocharis fessalis (Swinhoe, 1886), Autocharis ecthaemata (Hampson, 1913), Autocharis linealis Shaffer \& Munroe, 2007 and Autocharis marginata Guillermet, 1996. The transverse band of all these species occupies in average distal $20 \%$ of the forewing according to the data given in Shaffer and Munroe [5]. The transverse band of Autocharis discalis Shaffer \& Munroe, 2007 occupies distal $30 \%$ of the forewing. The transverse band in the forewing of the new species is even broader occupying distal $36 \%$ of the forewing. Furthermore, the forewing transverse band of the new species is dark brown interspersed with yellowish scales. The transverse band of Autocharis discalis Shaffer \& Munroe, 2007 is reddish-brown. The proximal margin of the transverse band in Autocharis discalis Shaffer \& Munroe, 2007 is marked by a prominent line of black scales, which is absent in the new species. Furthermore, the new species is distinguished from Autocharis discalis Shaffer \& Munroe, 2007 by the following features: Ground of forewing: yellow in Autocharis discalis Shaffer \& Munroe, 2007, whitish-grey in the new species, with the areas of yellow scales restricted to the costal border and the dark transverse band. Costal border of forewing: orange-brown in Autocharis discalis Shaffer \& Munroe, 2007, yellowish-brown in the new species. Hindwing: transverse band reddish-brown in Autocharis discalis Shaffer \& Munroe, 2007 , reddish scales absent in the hindwing transverse band of the new species. Distal two thirds of the CuA2 of Autocharis discalis Shaffer \& Munroe, 2007 marked with yellow scales, no yellow scales on the $\mathrm{CuA} 2$ of the new species. Labial palpus: marked with reddish-brown scales in Autocharis discalis Shaffer \& Munroe, 2007, reddish scales absent in the maxillary palpus of the new species. The labial palpus in both species is quasi triangular-shaped, with both lateral borders straight in Autocharis discalis Shaffer \& Munroe, 2007. The anterior border of the labial palpus of the new species has a prominent concave curvature. Thorax: The thorax of the new species has whitish-grey lateral borders covering its entire length, which are absent in the thorax of Autocharis discalis Shaffer \& Munroe, 2007. Tegula: The orange-brown line characteristic of Autocharis discalis Shaffer \& Munroe, 2007 is absent in the new species.

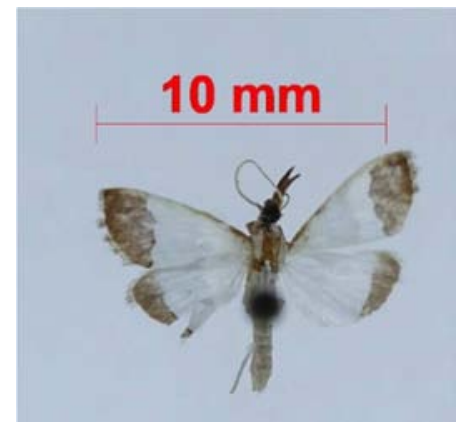

Figure 10. Autocharis arrondalis Seizmair sp. nov., holotype, adult.

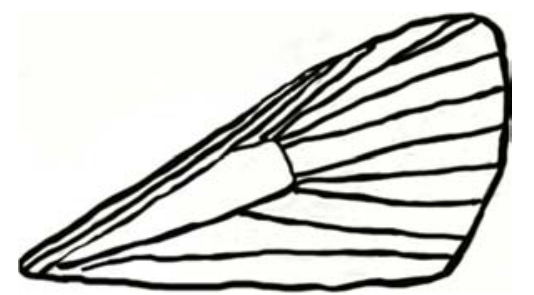

Figure 11. Autocharis arrondalis Seizmair sp. nov, holotype, forewing venation.

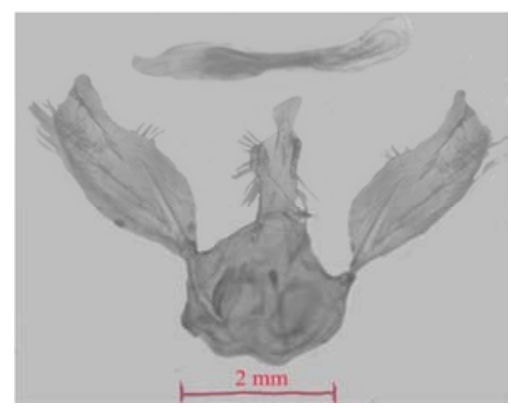

Figure 12. Autocharis arrondalis Seizmair sp. nov., holotype, male genitalia slide no. GPPYR3819.

The male genitalia of the new species are close to those of Autocharis fessalis (Swinhoe, 1886) and Autocharis linealis Shaffer and Munroe, 2007 with the following differences: Valva: costal borders of the new species and Autocharis fessalis (Swinhoe, 1886) sinuate, costal border of Autocharis linealis Shaffer \& Munroe, 2007 strongly convex. Dorsal border of Autocharis fessalis (Swinhoe, 1886) with a thorn-like projection, projections absent in the dorsal borders of the new species and of Autocharis linealis Shaffer \& Munroe, 2007. Apex of Autocharis linealis Shaffer \& Munroe, 2007 acute distally, apex of Autocharis fessalis 
(Swinhoe, 1886) quasi quadrangular, apex of the new species rounded. Uncus: lobe of Autocharis linealis Shaffer \& Munroe, 2007 heart-shaped, significantly broadening distally, lobe of Autocharis fessalis (Swinhoe, 1886) and of the new species oviform. Gnathos of Autocharis linealis Shaffer \& Munroe, 2007 rod-shaped, fine, gnathos of Autocharis fessalis (Swinhoe, 1886) and of the new species significantly broadened and mace-shaped. Tegumen: elongate, significantly longer than wide in Autocharis fessalis (Swinhoe, 1886) and Autocharis linealis Shaffer \& Munroe, 2007, tegumen of the new species as long as broad. Saccus: base of Autocharis fessalis (Swinhoe, 1886) and Autocharis linealis Shaffer \& Munroe, 2007 quasi flat, base of the new species with prominent convexity, with the lobes rounded proximally. Aedeagus: caecum of the new species straight, aedeagus of Autocharis fessalis (Swinhoe, 1886) and Autocharis linealis Shaffer \& Munroe, 2007 with $20^{\circ}$ curvatures in the caecum. The two posterior thirds of the caecum of the new species is significantly broader than the anterior third, the caecum of the other two species is of constant width.

Bionomics: Unknown. The types were collected in an escarpment at the border Oman-Yemen.

Distribution: Hitherto only known from the type locality. Neither endemism nor presence on the East African mainland can be excluded.

Etymology: The name refers to one of the characteristic features in the male genitalia, the rounded apex of the valva (latin: arrondare=round up).

\section{Conclusion}

In this paper occurrences of the Autocharis seyrigalis (Marion \& Viette, 1956) complex are reported for the first time for the Arabian Peninsula, which are attributed to the new species Autocharis trisignalis Seizmair, sp. nov. and Autocharis renalis Seizmair, sp. nov.. There is thus a wide distributional gap spanning $5000 \mathrm{~km}$ between the occurrences on the southern Arabian Peninsula and the next known occurrences of the species group in South Africa and the Malagasy region. Occurrences of still unknown species in between, i.e. East, Central and West Africa are highly probable.

The phylogenetic status of both of the two species complexes dealt with in this paper are still unexplored. Shaffer and Munroe conjecture that the Autocharis seyrigalis (Marion \& Viette, 1956) complex may have to be attributed to a separate genus still to be set up [5]. It is also probable that Autocharis arrondalis Seizmair, sp. nov. and Autocharis discalis Shaffer \& Munroe 2007 form a separate species complex distinguished from the Autocharis fessalis (Swinhoe, 1886) complex sharing as a common external feature the broadened transverse band on the forewing upperside making up $>30 \%$ of the forewing. The forewing transverse band of the other species of the Autocharis fessalis (Swinhoe, 1886) complex make up $<20 \%$ of the forewing.

For further understanding of the species complexes more details on the morphology will have to be explored. The male genitalia of Autocharis discalis Shaffer \& Munroe, 2007 are still unknown. More material is still necessary for making possible DNA- based phylogenetic analyses by using DNA barcoding methods to explore the phylogenetic relations between these species groups and the extent to which the species complexes are mirrored by species clusters based on genetic distance measures $[14,15]$. An attribution of the species groups discussed to new separate genera should only be done in a thoroughgoing revision of the entire group of genera Autocharis Swinhoe, 1854, Pseudonoorda Munroe, 1974 and Trigonoorda Munroe, 1974 [16].

\section{Acknowledgements}

The author thanks Prof. Gerhard Haszprunar (ZSM), Andreas Segerer (ZSM), Axel Hausmann (ZSM) and Wolfgang Speidel (ZSM and Museum Witt) for valuable discussion and support.

\section{References}

[1] J. De Prins and W. De Prins. "Afromoths, online database of Afrotropical moth species (Lepidoptera)," World Wide Web electronic publication (http://www.afromoths.net) [30.01.2020].

[2] [2\} M. Nuss, B. Landry, R. Mally, F. Vegliante, A. Tränkner, F. Bauer, J. Hayden, A. Segerer, R. Schouten, H. Li, T. Trofimova, M. A. Solis, J. De Prins and W. Speidel, "Global Information System on Pyraloidea," World Wide Web electronic publication (http://www.pyraloidea.org) [30.01.2020].

[3] J. E. F. Asselbergs, "Order Lepidoptera, superfamily Pyraloidea," in Arthropod fauna of the United Arab Emirates, Volume 1, Harten, A. van, Ed. Abu Dhabi: Dar Al Ummah Printing, Publishing, Distribution \& Advertising, 2008, pp. 469-561.

[4] H. Marion and P. Viette, "Pyrales de Madagascar nouvelles ou peu connues (Lepidoptera)," Mémoires de l'Institut Scientifique de Madagascar, Série Entomologie, vol. 7, pp. 77$115,1956$.

[5] J. C. Shaffer and E. G. Munroe, "Crambidae of Aldabra Atoll (Lepidoptera: Pyraloidea)," Tropical Lepidoptera, vol. 14, pp. 1-110, 2007.

[6] K. V. N. Maes, "Crambidae: Noordinae, Odontiinae, Pyraustinae, Spilomelinae (Lepidoptera, Pyraloidea)," in The Lepidoptera of the Brandberg Massif in Namibia, Part 1, Mey, W., Ed. Esperiana Memoir, vol. 1, pp. 221-234, 2004.

[7] W. Mey, "Basic pattern of Lepidoptera diversity in southwestern Africa," Esperiana Memoir, vol. 6, pp. 7-316, 2011.

[8] P. Viette and C. Guillermet, Lépidoptères Hétérocères de la Réunion (=Bourbon). La Réunion: Société réunionnaise des Amis du Muséum, Saint-Denis, 1996.

[9] C. Guillermet, Les Hétérocères, ou papillons de nuit, d l'île de La Réunion, Volume 3. La Réunion: Nature Découverte et Partage, 2009. 
[10] K. V. N. Maes, "Crambidae" in Classification and checklist of the species of Lepidoptera recorded from Southern Africa, Vári, L., Kroon, D. M. and Krüger, M., Eds. Simple Solutions, Australia, 2002, pp. 96-105.

[11] G. Robinson, "The Preparation of Slides of Lepidoptera Genitalia with Special Reference to the Microlepidoptera," Entomologist's Gazette, vol. 27, pp. 127 - 132, 1976.

[12] K. V. N. Maes, "A comparative morphological study of the adult Crambidae (Lepidoptera, Pyraloidea)," Bulletin et Annales de la Société Royale Entomologique de Belgique, Bruxelles, vol. 131, pp. 383-434.

[13] F. Slamka, Pyraloidea of Europe, Volume 1: Pyralinae,
Galleriinae, Epipaschiinae, Cathariinae, Odonttinae, Bratislava: Frantisek Slamka, 2006.

[14] S. Ratnasingham, "BOLD Barcode of Life Data System," World Wide Web electronic publication (www.boldsystems.org/views/login.php) [30.01.2020].

[15] S. Ratnasingham and P. D. N. Hebert, "BOLD: The Barcode of Life Data System (www.barcodinglife.org)," Molecular Ecology Notes 7, pp. 355-364, 2007.

[16] K. V. N. Maes, "New Pseudonoorda Munroe, 1974 species from Africa (Pyraloidea, Crambidae, Odontiinae)," Lambillionea, vol. 112, pp. 226-234, 2012. 